\title{
Changing Patterns in Lifestyle, Food Intake and Health Status between Selected Beneficiary People and Non- beneficiary People of Urban Slum in Dhaka City
}

\author{
M S Islam ${ }^{1}$, AAM Kurshed ${ }^{1}$, TMA Azad ${ }^{2}$ and M A H Bhuyan ${ }^{1}$ \\ Institute of Nutrition and Food Science, University of Dhaka ${ }^{1}$ \\ Dushtha Sasthya Kendra, Dhaka ${ }^{2}$
}

\begin{abstract}
:
To see the improvement in lifestyle, food intake and nutritional status of Beneficiary people of Shiree Project under Dushtha Shasthya Kendra, a comparative cross sectional study was done in Kamrangirchar slum among extreme poor people of Dhaka city and compared with non-beneficiary households. Beneficiary households of MDG-1 under Shiree Project got household economic intervention packages. In this stuy it is found that mean monthly income of the family was $6175.65 \mathrm{Tk}$ in beneficiary group and $4288.14 \mathrm{Tk}$ in non-beneficiary group. The mean monthly expenditure on food items of family was $3787.83 \mathrm{Tk}$ in beneficiary group and $2796.61 \mathrm{Tk}$ in non-beneficiary group. About 34 percent beneficiary households and 75 percent of all non-beneficiary households were poor having household's monthly income less than 3000 taka. Some 15.7 percent beneficiary households had five amenities out of selected six and only 1.7 percent non-beneficiary households had five amenities. So, socio-economic condition of beneficiary extreme poor people has improved. Consumption of food items was significantly more in beneficiary households than non-beneficiary ones. Some 74 percent beneficiary households consumed four or more food items daily and 26 percent non-beneficiary households consumed four or more food items daily. On average 3.37 food items were consumed by beneficiary households and 2.49 food items by non-beneficiary households daily. More than $60 \%$ of the beneficiary people ate full stomach meals and less than $25 \%$ of non-beneficiary people could afford to eat the same. So, beneficiary people were more food secure and more food diversified than non-beneficiary people. Nutritional status of the children by MUAC, Weight for Age Z-score, and Height for Age Z-score showed no significant difference between beneficiary and non-beneficiary group. Prevalence rate of underweight (Weight for Age Z-score) was 60.5\% in beneficiary children and $65.9 \%$ in non-beneficiary children. Significant difference $(\mathrm{P}=0.044)$ was found by Weight for Height Z-score in both beneficiary and non-beneficiary group.
\end{abstract}

Bangladesh Journal of Nutrition. Vol. 24-25 December, 2011-2012. Institute of Nutrition and Food Science, University of Dhaka, Dhaka-1000, Bangladesh.

* Author for Correspondence 
The difference of mothers' nutritional status by BMI between beneficiary group and non-beneficiary group was not statistically significant, though percentage of CED was lower and overweight was higher in beneficiary mothers than nonbeneficiary ones. Though socio-economic status, food security and food intake were better in beneficiary people than non-beneficiary ones, the outcome of these factors were not significant in clinical and anthropometric status. Beneficiary households were on the way to meet first target of MGD-1 which is related to poverty reduction. But they were far away from reaching the second target and halving prevalence of underweight as described in MDG-1.

Key Words: Extreme poor, Food Security, MDG, Stunting, Underweight, Wasting

\section{Introduction:}

All 189 member countries of United Nations joined at the Millennium Summit in September 2000 and settled to "eradicate extreme poverty and hunger", by reaching the target of halving (by 2015, as compared with 1990) the proportion of people who suffer from hunger. The earlier World Summit of all nations of UN for Children in 1990 and Millennium Development Goals in 2000 set a 50\% reduction in child underweight and poverty as the main objective. ${ }^{1}$ The total population of Dhaka increased from 1.98 million to 9.91 million between 1974 and 2001, experiencing a growth of $400 \%$ in that period. ${ }^{2}$ The total population living in the slums of Dhaka doubled between a range of 1.5 million in 1996 and 3.4 million in 2005, while the number of slum increased roughly by seventy percent ${ }^{3}$. If Bangladesh is to fulfill its commitment towards attaining the MDG, numerous extreme poor people require urgent and exceptional consideration. Dushtha Shasthya Kendra (DSK), a NGO, has developed five household economic intervention packages that include training, physical assets, cash stipends for pregnant and lactating mother, health services and water and sanitation support for beneficiary slum dwellers under "Shiree Project" to achieve MDG- $1^{4}$. With 4 years to come to achieve the MDGs, it is important to evaluate whether the nutrition program is on right track and where additional efforts and support are needed. Out of this concern, a study was conducted in a area where extreme poor people were under intervention to achieve MDG-1.

\section{Methodology:}

A comparative cross-sectional study was carried out among the households of Kamrangirchar slum in Dhaka city, Bangladesh. Comparison was made between beneficiary group of MDG-1 and non -beneficiary group. Beneficiary group of MDG-1 got household economic intervention packages that include training, physical assets, cash stipends for pregnant and lactating mother, health services and water and sanitation support. Non-beneficiary group consisted of same social and economic criteria. They, non-beneficiary households, fulfilled the criteria for 
getting those benefits but they did not get. Such two groups of people were selected to investigate the improvement of the program aiming to eradicate extreme poverty with a goal of acquiring Millennium Development Goal-1 (MGD-1). To see the improvement of beneficiary people, socio-economic information, food intake pattern, and household food security and anthropometric information (age, weight, height and MUAC) of mothers and children were taken. Total sample size was 150 where 100 were beneficiary and 50 were non-beneficiary households. To reach 100 beneficiary households and 50 non-beneficiary households, 50 households from each ward were targeted. From each wards 35 beneficiary households and 20 nonbeneficiary households were selected randomly with the help of list of SHIREE Project. 15 households more than sample sizes were selected to meet the refusal and migration of households. The study subjects were mothers of the households and their children aged 2-7 years. The beneficiary group was selected according tohousehold having no microcredit involvement, total household incone $3000 \mathrm{Tk}$. in 2009, house rent $\leq 1200 \mathrm{Tk}$. in 2009 and the non-beneficiary group was selected according to-household having no microcredit involvement, total household income $\leq 4500 \mathrm{Tk}$. in 2011, House rent $\leq 1500 \mathrm{Tk}$. in 2011. The information was obtained from DSK office. Beneficiary and non-beneficiary group were selected from same area. Before starting the field data collection, basic information of the location was collected with the cooperation of area manager of DSK, SHIREE Project. The mothers of target households were interviewed to collect data by door to door visit with the assistance of field officer of that project and Close-ended questionnaire, weighing scale, wooden height scale, MUAC tape were used to collect relevant information.

\section{Results:}

Table-01: Mean and Standard deviation of monthly average income, expenditure and saving of the family

\begin{tabular}{|l|c|c|c|c|}
\hline \multirow{2}{*}{ Variables } & \multicolumn{2}{|c|}{ Mean } & \multicolumn{2}{c|}{ Standard Deviation (SD) } \\
\cline { 2 - 5 } & Beneficiary & $\begin{array}{c}\text { Non- } \\
\text { beneficiary }\end{array}$ & Beneficiary & $\begin{array}{c}\text { Non- } \\
\text { beneficiary }\end{array}$ \\
\hline $\begin{array}{l}\text { Monthly income of } \\
\text { the family (TK) }\end{array}$ & 6175.65 & 4288.14 & 2456.41 & 1661.33 \\
\hline $\begin{array}{l}\text { Monthly expenditure } \\
\text { of the family (TK) }\end{array}$ & 5293.04 & 4042.37 & 2070.29 & 1225.76 \\
\hline $\begin{array}{l}\text { Monthly expenditure } \\
\text { on food items (TK) }\end{array}$ & 3787.83 & 2796.61 & 1636.11 & 936.60 \\
\hline
\end{tabular}


Bangladesh J. Nutr. Vol. 24-25 Dec 2011-2012

Table-02: Percent distribution of the households according to poverty by BBS

\begin{tabular}{|c|c|c|c|c|}
\hline \multirow[t]{2}{*}{ Poverty by BBS } & \multicolumn{2}{|c|}{ Group } & \multirow[t]{2}{*}{ Total } & \multirow{2}{*}{$\begin{array}{l}\text { Pearson } \\
\text { Chi-Square }\end{array}$} \\
\hline & Beneficiary & Non-beneficiary & & \\
\hline $\begin{array}{l}\text { Extreme poor } \\
\text { (Income } \leq 3000 \mathrm{TK} . \text { ) }\end{array}$ & $4.3 \%$ & $8.3 \%$ & $5.7 \%$ & \multirow[t]{4}{*}{$\mathrm{P}=0.000$} \\
\hline $\begin{array}{l}\text { Poor } \\
\text { (Income 3001-5000 } \\
\quad \text { TK) }\end{array}$ & $33.9 \%$ & $75.0 \%$ & $48.0 \%$ & \\
\hline $\begin{array}{l}\text { Not poor } \\
(\text { Income }>5000 \mathrm{TK})\end{array}$ & $61.7 \%$ & $16.7 \%$ & $46.3 \%$ & \\
\hline Total & $100.0 \%$ & $100.0 \%$ & $100.0 \%$ & \\
\hline
\end{tabular}

Table-03: Percent distribution of the households according to family amenities

\begin{tabular}{|l|c|c|c|}
\hline \multirow{2}{*}{$\begin{array}{l}\text { Presence of } \\
\text { family amenities }\end{array}$} & \multicolumn{2}{|c|}{ Group } & \multirow{2}{*}{$\begin{array}{c}\text { Pearson } \\
\text { Chi-Square }\end{array}$} \\
\cline { 2 - 3 } & Beneficiary & Non-beneficiary & \\
\hline Television & $33.9 \%$ & $6.7 \%$ & $\mathrm{~S}$ \\
\hline Radio & $2.6 \%$ & $3.4 \%$ & $\mathrm{NS}$ \\
\hline Mobile & $44.3 \%$ & $23.7 \%$ & $\mathrm{~S}$ \\
\hline Chair & $20.9 \%$ & $16.6 \%$ & $\mathrm{NS}$ \\
\hline Fan & $93.9 \%$ & $83.3 \%$ & $\mathrm{~S}$ \\
\hline Bed (khat) & $96.5 \%$ & $83.1 \%$ & $\mathrm{~S}$ \\
\hline
\end{tabular}

S- Significant, NS- Not Significant 
Rahman and Islam : Nutritional Status and Food Security

Table-04: Percent distribution of the households according to consumption of various food groups

\begin{tabular}{|l|l|c|c|}
\hline \multirow{2}{*}{ Food items } & \multirow{2}{*}{ Response } & \multicolumn{2}{|c|}{ Group } \\
\cline { 2 - 4 } & & Beneficiary & Non-beneficiary \\
\hline \multirow{2}{*}{ Citrus fruits } & Daily & $15.7 \%$ & $1.7 \%$ \\
\cline { 2 - 4 } & Weekly & $25.2 \%$ & $5.0 \%$ \\
\hline \multirow{2}{*}{ Leafy vegetables } & Daily & $85.2 \%$ & $70.0 \%$ \\
\cline { 2 - 4 } & Weekly & $12.2 \%$ & $18.3 \%$ \\
\hline \multirow{2}{*}{$\begin{array}{l}\text { vogeteafy } \\
\text { Colored vegetables }\end{array}$} & Daily & $86.1 \%$ & $56.7 \%$ \\
\cline { 2 - 4 } & Weekly & $7.0 \%$ & $25.0 \%$ \\
\cline { 2 - 4 } & Weekly & $26.1 \%$ & $15.0 \%$ \\
\hline
\end{tabular}

Figure-01: Percent distribution of the households according to consumption of four or more food items daily

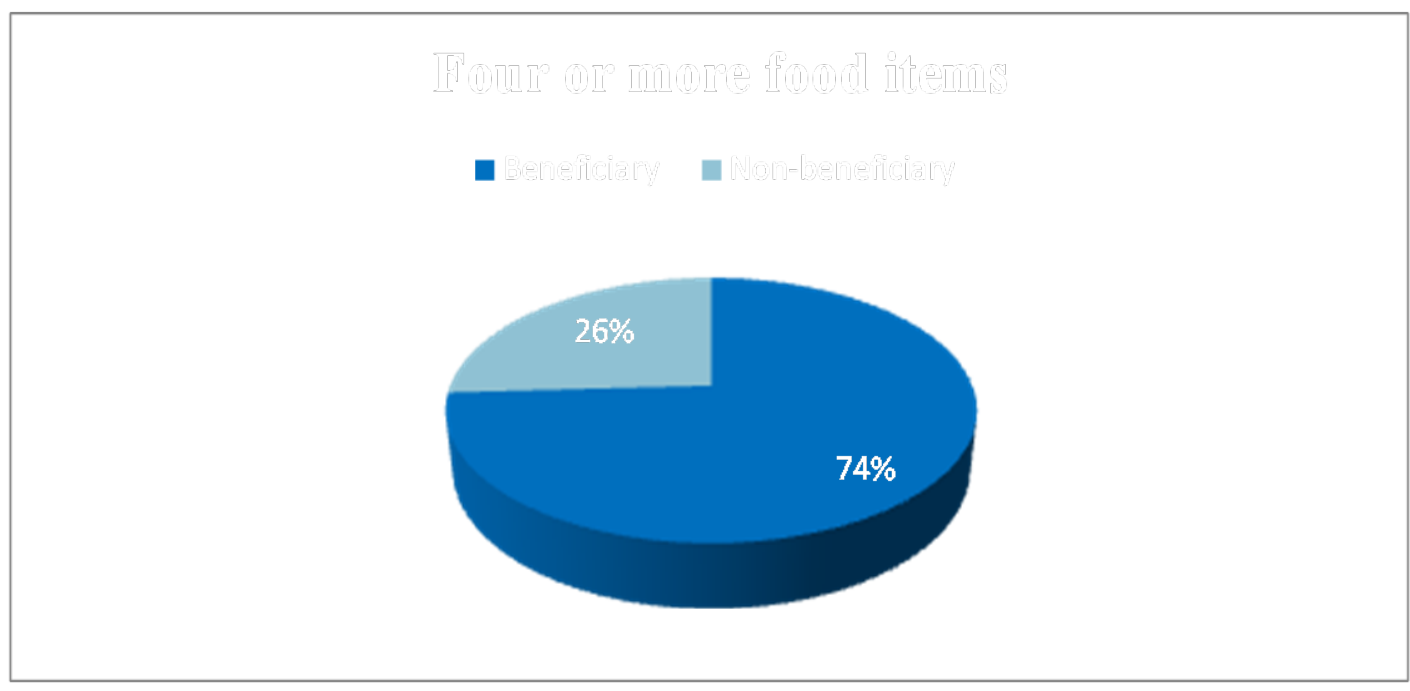


Figure-02: Mean of number of food item eating daily and weekly

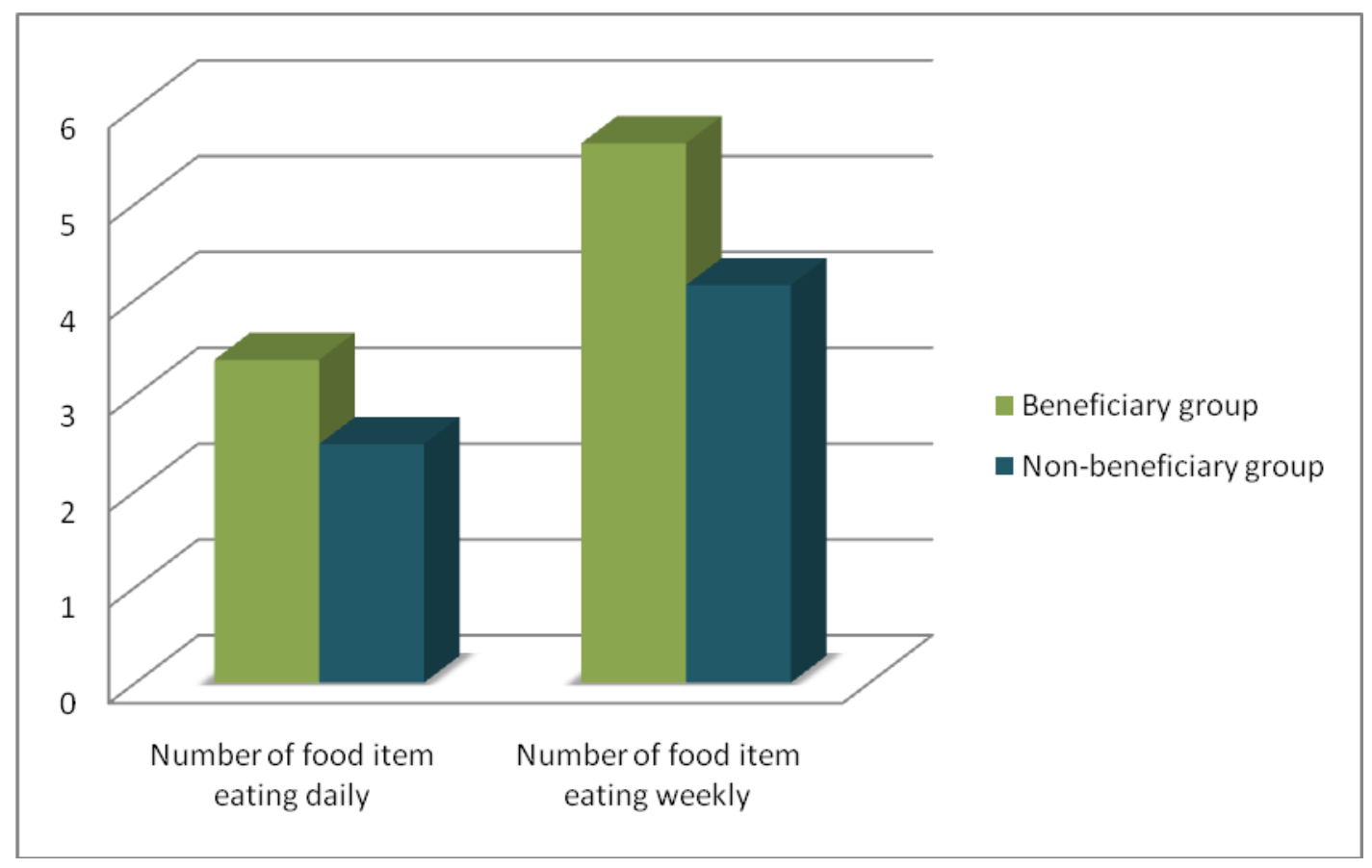

Figure-03: Percent distribution of the households according to eating three square meals (full stomach meals)

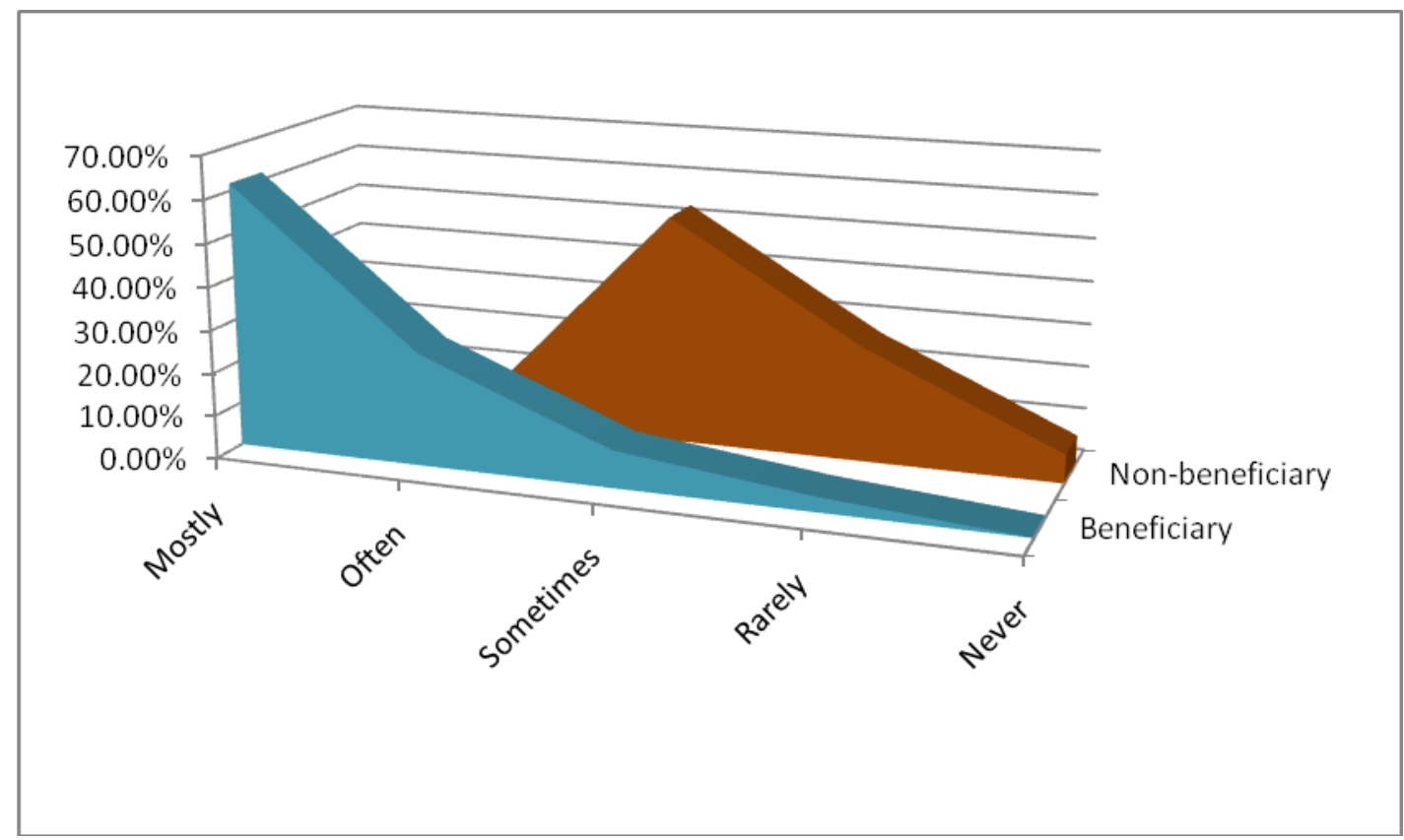


Rahman and Islam : Nutritional Status and Food Security

Table -05: Nutritional status of children:

\begin{tabular}{|c|c|c|c|c|}
\hline \multicolumn{2}{|l|}{ Nutritional Status } & \multicolumn{2}{|c|}{ Group } & \multirow{3}{*}{$\begin{array}{l}\text { Pearson } \\
\text { Chi-Square }\end{array}$} \\
\hline & & \multirow{2}{*}{$\begin{array}{c}\text { Beneficiary } \\
60.0 \%\end{array}$} & \multirow{2}{*}{$\begin{array}{l}\begin{array}{l}\text { Non- } \\
\text { beneficiary }\end{array} \\
74.3 \%\end{array}$} & \\
\hline MUAC & $\begin{array}{l}\text { Normal } \\
(\text { MUAC>13.5cm) }\end{array}$ & & & \\
\hline & $\begin{array}{l}\text { Mild malnourished } \\
\text { (MUAC 12.5-13.5) }\end{array}$ & $30.0 \%$ & $17.1 \%$ & \\
\hline & $\begin{array}{l}\text { Malnourished } \\
\text { (MUAC<12.5) }\end{array}$ & $10.0 \%$ & $8.6 \%$ & \\
\hline \multirow{2}{*}{$\begin{array}{l}\text { Height for Age Z } \\
\text { score (HAZ) }\end{array}$} & Normal ( $\geq-2 S D)$ & $42.0 \%$ & $52.3 \%$ & \multirow[t]{2}{*}{$\mathrm{P}=0.270$} \\
\hline & Stunting $(<-2 S D)$ & $58.0 \%$ & $47.7 \%$ & \\
\hline \multirow{2}{*}{$\begin{array}{l}\text { Weight for Age Z } \\
\text { score (WAZ) }\end{array}$} & Normal ( $\geq-2 S D)$ & $39.5 \%$ & $34.1 \%$ & \multirow[t]{2}{*}{$\mathrm{P}=0.551$} \\
\hline & Underweight (<-2SD) & $60.5 \%$ & $65.9 \%$ & \\
\hline \multirow{2}{*}{$\begin{array}{l}\text { Weight for Height Z } \\
\text { score (WHZ) }\end{array}$} & Normal $(\geq-2 S D)$ & $74.1 \%$ & $59.1 \%$ & \multirow[t]{2}{*}{$\mathrm{P}=0.044$} \\
\hline & Wasting (<-2SD) & $25.9 \%$ & $40.9 \%$ & \\
\hline
\end{tabular}

Figure-04: Percent distribution of the respondents according to nutritional status by BMI

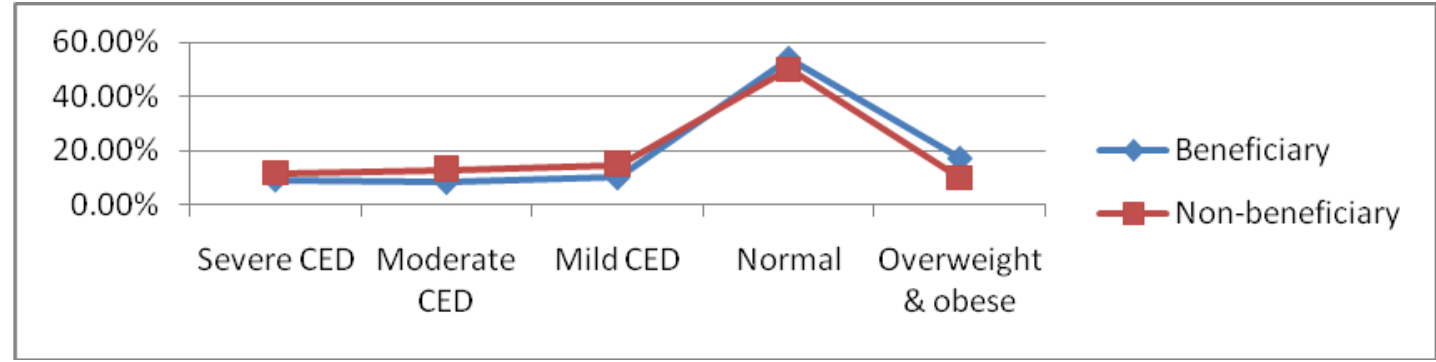

\section{Discussion:}

To eradicate poverty, various programs are running but very few studies had been done regarding the improvement of these programs. Out of this concern and also to see the extend of attainment of MDG-1 by extreme poor people, a study was conducted in DSK- Shiree Project.

According to the table 1 of this syudy, the mean of monthly income of the family was 6175.65 Tk in beneficiary group and $4288.14 \mathrm{Tk}$ in non-beneficiary group which is much lower than national average income, Tk. $11,480^{5}$. The average total monthly expenditure was $5293.04 \mathrm{Tk}$ in beneficiary families and $4042.37 \mathrm{Tk}$ in non-beneficiary families. In 2010, the average monthly household expenditure was estimated at Tk. 11,200 at the national level, Tk. 9,612 in rural area and Tk. 15,531 in urban area ${ }^{5}$. The mean monthly expenditure on food items of family was $3787.83 \mathrm{Tk}$ in beneficiary group and $2796.61 \mathrm{Tk}$ in non-beneficiary group. Table 2 shows differences of poverty in beneficiary and non-beneficiary group according. It shows that about 34 percent beneficiary households and three-fourth of all non-beneficiary households were poor and 61.7 percent beneficiary households and 16.7 percent non-beneficiary households were not poor. Table 3 presents the presence of television (33.9\% vs 6.7\%) and 
mobile phone (44.3\% vs $23.7 \%$ ) were higher in beneficiary group than non-beneficiary group and this difference was significant.

As shown in table 4, percentage of households based on daily consumption of citrus fruits, leafy and non-vegetables were $15.7 \%, 85.2 \%$ \& $86.1 \%$ respectively for beneficiary households while the values were $1.7 \%, 70.0 \%$ and $56.7 \%$ respectively for non-beneficiary households. According to the Figure-1, 74 percent beneficiary households consumed four or more food items daily and 26 percent non-beneficiary households consumed four or more food items daily. Figure-2 shows that on average 3.37 food items were consumed by beneficiary households and 2.49 food items by non-beneficiary households daily. It also shows that mean weekly number of food intake was 5.63 in beneficiary households and 4.15 in non-beneficiary households. Figure-03 elicits the pattern of eating three square meals (full stomach meals) among beneficiary and non-beneficiary households. About 62 percent of the beneficiary people could afford to eat mostly three square meals while 26.1 percent people could afford to eat the same often, and more than seventy- five percent non-beneficiary people could not attend to eat full stomach meals. Beneficiary people were more food secure than non-beneficiary people. Table 5 presents nutritional status of the children. In beneficiary group, $30 \%$ children were mild malnourished and $10 \%$ children were malnourished according to MUAC status. In nonbeneficiary group, $17.1 \%$ children were mild malnourished and $8.6 \%$ children were malnourished. It is also revealed that $58.0 \%$ were stunted among beneficiary children and $47.7 \%$ among non-beneficiary ones. Again, the prevalence of underweight among beneficiary children was about $60 \%$ and among non-beneficiary children it was about $66 \%$.though the prevalence of underweight was apparently higher among non-beneficiary children than the beneficiary ones, the difference was not statistically significant. About $25.9 \%$ children in beneficiary group were wasted while $40.9 \%$ children in non-beneficiary group were wasted, and the difference was statistically significant. The national prevalence of underweight, stunting and wasting in 2007 were $41 \%, 43 \%$ and $17 \%$ respectively ${ }^{6}$. Underweight, stunting and wasting rates in extreme poor households (both beneficiary and non-beneficiary) are much higher than national level. Figure-04 shows nutritional status of beneficiary and non-beneficiary mothers by BMI. It is revealed that severe, moderate and mild chronic energy deficiency was higher among non-beneficiary mothers as compared with beneficiary ones. Moreover proportion obese mothers were higher among beneficiary group than non-beneficiary ones though the difference between beneficiary group and non-beneficiary groups was not statistically significant.

\section{References:}

1. Road map towards the implementation of the United Nations Millennium Declaration. Report of the Secretary General. A/56/326. United Nations Statistic Division, New York.

2. BBS (1997): Bangladesh Population Census 1991 Urban Area Report. Dhaka, BBS: Ministry of Planning

3. Bangladesh Census of Urban Slums, 2005. NIPORT, Dhaka.

4. Improving Health Outcomes of the Poor: the report of working group 5 of the Commission on Macroeconomics and Health.

Online: http://www3.who.int/whosis/cmh/cmh_papers/e/pdf/wg5_summary.pdf

5. Household Income \& Expenditure Survey-2010, 2011, Bangladesh Bureau of Statistics: Dhaka.

6. Bangladesh Demographic and Health Survey, NIPORT, Final Report, 2007 